\title{
LÄMPÖTILAN JA POUTAJAKSON VAIKUTUS JAUHOSAVIKAN (CHENOPODIUM ALBUM L.) JA VILJAN VÄLISEEN KILPAILUUN
}

\author{
LeILA-RittTa ERviö \\ Helsingin yliopiston kasvinviljelytieteen laitos
}

Saapunut 5. 4. 1972

\begin{abstract}
THE EFFECT OF TEMPERATURE AND DRY-WEATHER PERIOD ON THE COMPETITION BETWEEN CHENOPODIUM ALBUM L. AND SOME SPRING CEREALS
\end{abstract}

\author{
LeILA-RittTa Erviö \\ Institute of Plant Husbandry, University of Helsinki
}

\begin{abstract}
The effect of temperature on C. album and oats (Experiment I) was studied in phytotrons at the temperatures of $24^{\circ}$ and $12^{\circ} \mathrm{C}$. The effect of a dry-weather period on C. album and wheat (Experiment II) was studied in a roofed coolhouse for pot experiments.

Experiment I. Both C. album and oats developed much faster at $24^{\circ}$ than at $12^{\circ} \mathrm{C}$. At $24^{\circ} \mathrm{C}$ equal temperature summations were needed for both species to reach the two-leaf stage; from that stage on the temperature requirement of $C$. album was less than that of oats. At $12^{\circ} \mathrm{C}$ oats were able to attain the two-leaf stage at a lower temperature summation than C. album. The low temperature was found to retard the weight increase of C. album more than that of oats.

The yields per unit area of pure stands of oats and $C$. album were almost as large as the yield from a mixed population. The competition between the two species did not affect the individual plant weight of $C$. album significantly but it did reduce the plant weight and total yield of oats. In a mixed stand $C$. album accounted for $22.6 \%$ and oats for $77.4 \%$ of the total yield.
\end{abstract}

Experiment II. A period of dry weather had no effect on the growth of C. album but reduced the individual plant weight and total yield of wheat. The greatest yield reductions were found when a dry period occurred at the seedling stage of wheat.

Competition with $C$. album reduced the plant weight and total yield of wheat. The plant weight of $C$. album remained lower in intraspecific competition than in a mixed population with wheat. The increase in plant weight during the growing period was proportionally larger for $C$. album than for wheat. The weight of $C$. album increased more in a mixed stand than in a pure one, while the reverse was true for wheat. C. album accounted for $65.3 \%$, wheat for $34.7 \%$ of the total yield of a mixed stand.

C. album proved a stronger competitor than wheat; its invasion coefficient was considerably higher than that of wheat. 


\section{Fohdanto}

Pellon ekosysteemissä viljelykasvit joutuvat kilpailemaan kasvutekijöistä paitsi keskenään myös rikkakasvien kanssa. Kasvit ovat kilpailukyvyltään varsin erilaisia. Esimerkiksi viljoista kauraa ja ohraa pidetään varjostavuutensa vuoksi tehokkaina rikkakasvien kilpailijoina, kun taas niukasti versova vehnä on heikko. Rikkakasveista on mm. rikkasinappi (Sinapis arvensis) osoittautunut erittäin aggressiiviseksi sekä viljojen että toisten rikkakasvilajien kanssa kilpaillessaan (RAdemacher 1964, IdRIs ja Milthorpe 1966, Косн 1967).

Eräänä lauhkean vyöhykkeen yleisimmistä rikkakasveista jauhosavikka sisältyy moniin tutkimuksiin, jotka käsittelevät rikkakasvuston vaikutusta viljelykasveihin (mm. Martin ja Rademacher 1960, Rademacher ym. 1961, Baker ym. 1963, Dawson 1964). Sen kilpailukykyä toisena osapuolena viljelykasvien kanssa ovat tutkineet mm. GraNströм (1962) ja Williams (1964). Helsingin yliopiston kasvinviljelytieteen laitoksella on aikaisemmin selvitetty jauhosavikan lajinsisäistä kilpailua (ERvıö 1971, 1972), ja tutkimuksia jatkettiin vuosina $1969-70$ astiakokeina, joissa selvitettiin kasvuolojen vaikutusta jauhosavikan ja viljojen väliseen kilpailuun.

\section{Tutkimusaineisto ja -menetelmät}

K o e I. Lämpötilan vaikutusta jauhosavikkaan ja kauraan tutkittiin fytotroneissa $24^{\circ}$ ja $12^{\circ} \mathrm{C}$ :n lämpötiloissa. Valaistuksen voimakkuus kasvien korkeudella oli 16000 luxia ja valoisan ajan pituus vuorokaudessa säädettiin 20 tunniksi. Muoviset kasvatusastiat, joiden pinta-ala oli $200 \mathrm{~cm}^{2}$ ja tilavuus $21 / 2$ litraa, täytettiin kasvuturpeen (valmiiksi lannoitettu St-400-turve) ja hiekan seoksella suhteessa 3:1. Kokeen aikana varmistettiin kasvien runsas ravinteiden saanti lannoiteliuoskastelulla. Kerranteita oli neljä. Astioihin kylvettiin jauhosavikkaa ja Sisu-kauraa seuraavanlaisten kasvustojen saamiseksi:

Puhdas kaurakasvusto, jonka tiheys oli $500 \mathrm{kpl} / \mathrm{m}^{2}$

Jauhosavikan ja kauran sekakasvusto (suhde 1:1), jonka tiheys oli $1000 \mathrm{kpl} / \mathrm{m}^{2}$

Puhdas jauhosavikkakasvusto

Puhtaan kaurakasvuston yksilömäärä oli puolta pienempi kuin muiden kasvustojen, koska sen tarkoituksena oli edustaa rikkakasvittomana pidettyä viljakasvustoa. Sekakasvusto, jonka tiheys oli 500 jauhosavikka- ja 500 kaurayksilöä/m² edusti viljelystä, jolla rikkakasvien torjuntaa ei ole suoritettu (Mukula ym. 1969). Puhtaan savikkakasvuston yksilömäärä oli sama kuin sekakasvuston, jotta voitaisiin vertailla lajinsisäisen ja lajien välisen kilpailun vaikutusta jauhosavikkaan.

Kasvien maanpäällisten osien sato korjattiin 2 kk:n kuluttua kylvöstä. Kummankin lajin kuiva-ainesato punnittiin ja kasvien yksilönpainot laskettiin kokonaissadon ja yksilömäärän perusteella.

K o e I I. Poutajakson vaikutusta jauhosavikkaan ja kevätvehnään tutkittiin astiakoehallissa, jossa keskimääräinen lämpötila kokeen aikana oli $16.8^{\circ} \mathrm{C}$ (vaihtelu $13.5^{\circ}$ $21.0^{\circ} \mathrm{C}$ ). Jauhosavikkaa ja Svenno-vehnää kasvatettiin kolmena kerranteena lysimetreissä (JuUsELA 1962), joissa kasvien vedensaanti voitiin säännöstellä. Astioiden pinta- 
ala oli $706 \mathrm{~cm}^{2}$ ja tilavuus n. 33 litraa. Kasvualustana oli pellon muokkauskerroksesta otettu hieno hietamaa. Laatikoihin kylvetyt ja koulitut, kasvihuoneessa 6-8-lehtiasteelle kehittyneet jauhosavikan taimet sekä koekentällä kasvaneet, 3-lehtiasteella olleet vehnän oraat istutettiin lysimetriastioihin seuraavanlaisiksi kasvustoiksi:

1) Puhdas vehnäkasvusto

2) Jauhosavikan ja vehnän sekakasvusto suhteessa 1:1

3) Puhdas jauhosavikkakasvusto

Tässä kokeessa kaikkien kasvustojen tiheys oli n. $1000 \mathrm{kpl} / \mathrm{m}^{2}$ (= $70 \mathrm{kpl} /$ astia), koska tarkoituksena oli poudan vaikutuksen ohella verrata myös lajinsisäisen ja lajien välisen kilpailun vaikutusta kumpaankin koekasviin. Istutusvaiheessa määritettiin kummankin kasvilajin keskimääräinen yksilönpaino $2 \times 5 \mathrm{kpl}$ :n erästä. Tämän perusteella saatiin myöhemmin lasketuksi yksilöitten painonlisäys kokeen aikana.

Kasvien vedensaanti järjestettiin siten, että verrannekoejäsenet saivat vapaasti vettä kokeen aikana. Muitten koejäsenten vedensaanti säännösteltiin sulkemalla kasvatusastioihin johtavat vesiletkut jauhosavikan kukinnan alkaessa (vehnä orasasteella) ja täyden kukinnan aikaan (vehnän tähkät tupessa). Kasvualusta sai kuivua, kunnes jauhosavikat joutuivat plasmolyysiin. Siihen kulunut aika oli keskimäärin 20 vuorokautta. Poutajakson jälkeen kasveille annettiin jälleen vapaasti vettä kokeen lopettamiseen saakka.

Jauhosavikan kellastuttua ja vehnän ollessa maito- ja keltatuleentumisvaiheitten välillä korjattiin kasvien kokonaissadot, jotka käsiteltiin samoin kuin kokeessa I.

\section{Tulokset}

Koe I. Lämpötilan vaikutus jauhosavikkaan ja kauraan. Jauhosavikka ja kaura kehittyivät huomattavasti nopeammin $24^{\circ}$ kuin $12^{\circ} \mathrm{C}: \mathrm{n}$ lämpötilassa. Kun ne korjattiin kahden kuukauden kuluttua kylvöstä, olivat puhtaan kasvuston jauhosavikat $24^{\circ} \mathrm{C}$ :ssa kukintansa loppuvaiheessa, mutta siementen kehitys ei vielä ollut alkanut. Sekakasvustossa jauhosavikkaan oli kehittynyt kukkien lisäksi hiukan siemeniä, jotka eivät kuitenkaan vielä varisseet. Samana ajankohtana $12^{\circ} \mathrm{C}$ :ssa oli jauhosavikoissa $6-8$ lehteä. Kukintojen latvat olivat näkyvissä sekä ensimmäisten haarojen silmut kehittyneet lehtihankoihin. Voimakkain vegetatiivinen kasvu ei siis vielä ollut alkanutkaan. Kokeen päättyessä kauran jyvien muodostuminen oli alkanut $24^{\circ} \mathrm{C}$ :ssa, mutta $12^{\circ} \mathrm{C}$ :ssa kaurayksilöt olivat vasta keskimäärin 4-lehtiasteella.

Eri kehitysvaiheittensa saavuttamiseen kasvit tarvitsivat taulukossa 1 esitetyt lämpötilasummat. Alkukehitykseensä 2-lehtiasteelle saakka jauhosavikka ja kaura tarvitsivat $24^{\circ} \mathrm{C}$ :ssa samat lämpötilasummat. Kauran sivuversojen alkaessa muodostua oli jauhosavikka saavuttanut nuppuasteen. Jauhosavikan kukinta alkoi ennen kauran röyhylletuloa ja jatkui ohi kauran kukkimisvaiheen.

Lämpötilan ollessa $12^{\circ} \mathrm{C}$ kauran alkukehitykseen riitti pienempi lämpötilasumma kuin jauhosavikalle: Taimettuakseen jauhosavikka tarvitsi noin kaksinkertaisen lämpötilasumman kauran orastumiseen verrattuna ja 2-lehtiasteelle kehittyäkseen yli kaksinkertaisen lämpötilasumman kauran 2-lehtiasteeseen nähden. Jauhosavikan haarojen kehittyminen ja kauran pensominen alkoivat samanaikaisesti $12^{\circ} \mathrm{C}$ :ssa lämpötilasumman ollessa $504^{\circ} \mathrm{C}$. 
Taulukko 1. Jauhosavikan ja kauran kehitysasteiden saavuttamiseen tarvitut lämpötilasummat $24^{\circ}$ ja ja $12^{\circ} \mathrm{C}: n$ lämpötiloissa.

Table 1. Temperature summations required for C. album and oats to attain different developmental stages at temperatures of $24^{\circ}$ and $12^{\circ} \mathrm{C}$.

Kasvi ja kehitysaste

Species and developmental stage
Lämpötilasummat

Temperature summations $12^{\circ} \mathrm{C}$

J a u hos avikka - C. album

Taimettunut - Emerged

$72 \quad 180$

2-lehtiaste - Two-leaf stage

192

432

Haarojen kehitys alkanut - Branching begun

360

504

8-10-lehtiaste $-8-10$ leaf stage

$528 \quad 708$

Nuppuaste - Flower-bud stage

864

Kukinta alkanut - Flowering begun

Kukinta päättynyt - Flowering ended

888

1416

K a u r a Oats

Orastunut - Emerged

$72 \quad 96$

2-lehtiaste - Two-leaf stage

$192 \quad 180$

Sivuversojen kehitys alkanut - Tillering begun

864

1008

Röyhyaste - Headed

1032

Kukinta-aste - Flowering

Jyvät kehittymässä - Grains developing

Kauran kehittymiseen 2-lehtiasteelle ja pensomisen alkuun riitti pienempi lämpötilasumma $12^{\circ}$ kuin $24^{\circ} \mathrm{C}$ :ssa, kun taas jauhosavikka tarvitsi vastaavien kehitysasteittensa saavuttamiseen suuremmat lämpötilasummat $12^{\circ}$ kuin $24^{\circ} \mathrm{C}$ :ssa.

Kasvien yksilönpainot ja kokonaissadot (kuva 1) pinta-alayksikköä kohti olivat kokeen päättyessä kaikissa kasvustoissa suuremmat $24^{\circ}$ kuin $12^{\circ} \mathrm{C}$ :ssa, jossa kasvit olivat vasta kehityksensä alussa.

Alhainen lämpötila pienensi enemmän jauhosavikan kuin kauran keskimääräistä painon nousua kokeen aikana, kuten oheiset suhdeluvut osoittavat:

$\begin{array}{lccc} & & 24^{\circ} \mathrm{C} & 12^{\circ} \mathrm{C} \\ & & \mathrm{S} . & \mathrm{S} l . \\ \text { Jauhosavikka } & 0.56 \mathrm{~g} / \text { yksilö }= & 100 & 39 \\ \text { Kaura } & 1.14 \quad, & 100 & 94\end{array}$

Jauhosavikan keskimääräisten yksilönpainojen väliset erot puhtaassa ja sekakasvustossa eivät osoittautuneet tilastollisesti merkitseviksi, kun taas kauran yksilönpaino aleni selvästi (F 7.26*) jauhosavikan ollessa mukana kasvustossa:

$\begin{array}{clc} & & \text { Suhdeluvut } \\ \text { Yksilönpaino } & \text { puhtaassa kasvustossa } & 100 \\ ,, & \text { sekakasvustossa } & 80\end{array}$




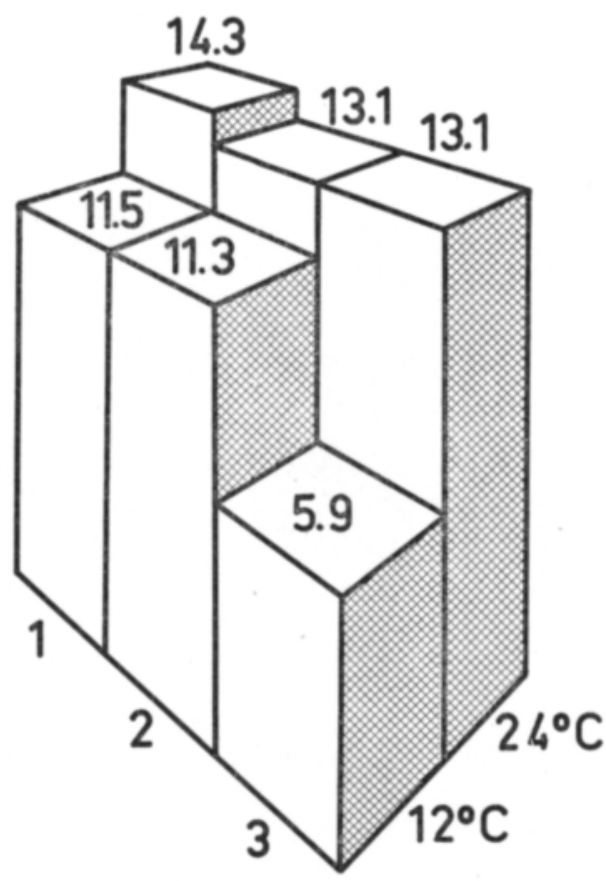

Kuva 1. Lämpötilan vaikutus jauhosavikan ja kauran sekä näiden sekakasvuston satoon. $1=$ sekakasvusto, 2 = puhdas kaurakasvusto, 3 = puhdas jauhosavikkakasvusto.

Fig. 1. Effect of temperature on the yields of mixed and pure stands of $C$. a $l \mathrm{~b} u \mathrm{~m}$ and oats. $1=$ mixed stand, $2=$ pure oats, 3 = pure $C$. al $b u \mathrm{~m}$.

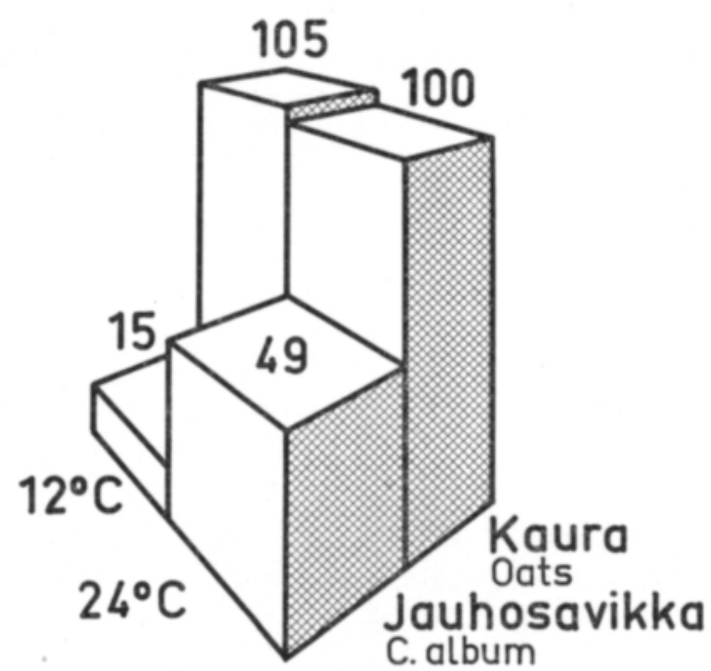

Kuva 2. Lämpötilan vaikutus jauhosavikan ja kauran suhteellisiin satoihin sekakasvustossa.

Fig. 2. Effect of temperature on the relative yields of $C$. $a l b u m$ and oats in a mixed stand. 
Jauhosavikan ja kauran puhtaiden kasvustojen pinta-alayksiköltä tuottamat sadot eivät poikenneet merkitsevästi sekakasvuston sadosta (kuva 1), vaikka yksilöitä oli kaurakasvustossa vain puolet sekakasvuston yksilömäärästä. Jauhosavikan ja kauran kilpailu sekakasvustossa alensi kauran kokonaissatoa puhtaaseen kasvustoon verrattuna samassa suhteessa kuin yksilönpainoakin. Jauhosavikan sato jäi sekakasvustossa selvästi pienemmäksi (F 38.57**) kuin kauran (kuva 2) varsinkin $12^{\circ} \mathrm{C}:$ :n lämpötilassa. Sen keskimääräinen osuus sekakasvuston sadosta oli $22.6 \%$ ja kauran $77.4 \%$.

Koe II. Poutajakson vaikutus jauhosavikkaan ja vehnään. Jauhosavikka kehittyi kokeen aikana nopeammin kuin vehnä:

$\begin{array}{ll}\text { Jauhosavikka: } & \\ \text { Kukinta alkanut } & 10 \\ \text { Kukinta parhaimmillaan } & 18 \\ \text { Kukinta päättynyt } & 24 \\ \text { Siemenet kehittymässä } & 35 \\ \text { Kasvien kellastuminen alkanut } & 59 \\ \text { Siementen variseminen alkanut } & 67 \\ & \\ \text { Vehnä: } & 10 \\ \text { 4-lehtiaste } & 22 \\ \text { Sivuversojen kehitys alkanut } & 31 \\ \text { Tähkäaste } & 38 \\ \text { Kukinta alkanut } & 44 \\ \text { Jyvät kehittymässä } & 67 \\ \text { Maito-keltatuleentumisaste (pääverso) } & \end{array}$

Kun jauhosavikka kukki parhaimmillaan, tuntui vehnän tähkä lehtitupessa vasta muutamissa yksilöissä. Jauhosavikan kukinta oli loppunut vehnän tullessa tähkälle, ja jauhosavikan siemenet olivat jo kehittymässä, kun vehnä vasta alkoi kukkia. Jauhosavikan siemenet olivat muuttuneet ruskeiksi ja varisivat vehnän ollessa maito- ja keltatuleentumisasteiden välillä.

Veden säännöstelyn aiheuttama poutajakso ei vaikuttanut jauhosavikkayksilöitten painoon. Sen sijaan se aiheutti vehnän yksilönpainon alenemisen (taulukko 2). Puhtaassa kasvustossa poutajakson ajankohdalla ei ollut merkitystä, mutta sekakasvustossa vehnän yksilönpaino aleni merkitsevästi vain silloin, kun vettä oli niukasti saatavilla orasasteella.

Poutajakso alensi vehnäkasvuston sekä jauhosavikan ja vehnän seoksen, mutta ei puhtaan jauhosavikkakasvuston kokonaissatoa (taulukko 3). Vehnäkasvuston sato väheni voimakkaimmin, kun kuiva kausi sattui vehnän orasasteella. Sekakasvuston sadon alennus johtui pääasiallisesti vehnän sadon pienenemisestä.

Puhtaan kasvuston jauhosavikkayksilöt painoivat vähemmän (F 11.95**), vehnäyksilöt taas enemmän (F 30.33**) kuin kasvaessaan sekakasvustona (taulukko 2). Jauhosavikan keskimääräinen yksilönpaino oli puhtaassa kasvustossa $1.05 \mathrm{~g}$ ja sekakasvustossa 1.57 g. Kokeen aikana jauhosavikan yksilönpaino lisääntyi enemmän kuin vehnän. 
Taulukko 2. Poutajakson ja kilpailun vaikutus vehnän yksilönpainoon. Poutajaksot: $1=$ ei poutaa, $2=$ jauhosavikan kukinnan alkaessa (vehnä orasasteella), 3 = jauhosavikan täyden kukinnan aikaan (vehnän tähkät tupessa).

Table 2. Effect of dry-weather period and competition on the individual weight of wheat plants. $1=$ no dry-weather period, $2=$ dry weather during early flowering of C. album (wheat at seedling stage), $3=$ dry weather during ful flowering of C. album (wheat ears enclosed in sheaths).

\begin{tabular}{lccc}
\hline $\begin{array}{l}\text { Kasvusto } \\
\text { Stand }\end{array}$ & \multicolumn{2}{c}{$\begin{array}{c}\text { Paino g/yksilö }{ }^{1} \text { ) } \\
\left.\text { Weight per plant } g^{1}\right)\end{array}$} \\
\cline { 2 - 4 } & 1 & 2 & 3 \\
\hline $\begin{array}{l}\text { Puhdas kasvusto }- \text { Pure stand } \\
\text { Sekakasvusto }- \text { Mixed stand }\end{array}$ & $1.80^{\mathrm{d}}$ & $1.01^{\mathrm{bc}}$ & $1.30^{\mathrm{c}}$ \\
& $0.90^{\mathrm{bc}}$ & $0.72^{\mathrm{a}}$ & $0.89^{\mathrm{bc}}$
\end{tabular}

1) Luvut, joiden yläindeksiin sisältyy sama kirjain, eivät poikkea merkitsevästi toisistaan.

1) Superscripts which include the same letter indicate differences that are not significant.

Taulukko 3. Poutajakson ja kilpailun vaikutus puhtaan jauhosavikka- ja vehnäkasvuston sekä näiden sekakasvuston satoihin. Poutajaksot: $1=$ ei poutaa, $2=$ jauhosavikan kukinnan alkaessa (vehnä orasasteella), 3 = jauhosavikan täyden kukinnan aikaan (vehnän tähkät tupessa).

Table 3. Effect of dry-weather period and competition on the yields of pure and mixed stands of $C$. album and wheat. $1=$ no dry-weather period, $2=d r y$ weather during early flowering of C. album (wheat at seedling stage), $3=d r y$ weather during full flowering of $C$. album (wheat ears enclosed in sheaths).

\begin{tabular}{lrcc}
\hline $\begin{array}{l}\text { Kasvusto } \\
\text { Stand }\end{array}$ & \multicolumn{2}{c}{$\begin{array}{c}\text { Sato g/astia } \\
\text { Yield per pot } \text { g }^{1} \text { ) }\end{array}$} \\
\cline { 2 - 4 } & \multicolumn{2}{c}{3} \\
\hline Puhdas jauhosavikkakasvusto - Pure stand of C. album & $72^{\mathrm{a}}$ & $74^{\mathrm{a}}$ & $74^{\mathrm{a}}$ \\
Puhdas vehnäkasvusto - Pure stand of wheat & $124^{\mathrm{c}}$ & $71^{\mathrm{a}}$ & $91^{\mathrm{b}}$ \\
Sekakasvusto - Mixed stand & $90^{\mathrm{b}}$ & $80^{\mathrm{a}}$ & $82^{\mathrm{a}}$
\end{tabular}

1) Luvut, joiden yläindeksiin sisältyy sama kirjain, eivät poikkea merkitsevästi toisistaan.

1) Superscripts which include the same letter indicate differences are not significant.

Yksilöitten suhteellinen painonlisäys istutusvaiheesta korjuuseen oli keskimäärin seuraava (paino istutusvaiheessa $=100)$ :

$\begin{array}{lcc} & \text { Jauhosavikka } & \text { Vehnä } \\ \text { Puhdas kasvusto } & 525 & 394 \\ \text { Sekakasvusto } & 790 & 240\end{array}$

Jauhosavikan painonlisäys yksilöä kohti oli suurempi seka- kuin puhtaassa kasvustossa, kun taas vehnän painonlisäys oli suurempi puhtaassa kuin sekakasvustossa (kuva 3).

Puhtaan jauhosavikka- ja vehnäkasvuston sekä näiden sekakasvuston sadot poikkesivat toisistaan merkitsevästi (taulukko 3), kun vettä ei säännöstelty. Jauhosavikka tuotti tällöin pienimmän ja vehnä suurimman sadon. Orasasteella aiheutetun poudan vaiku- 


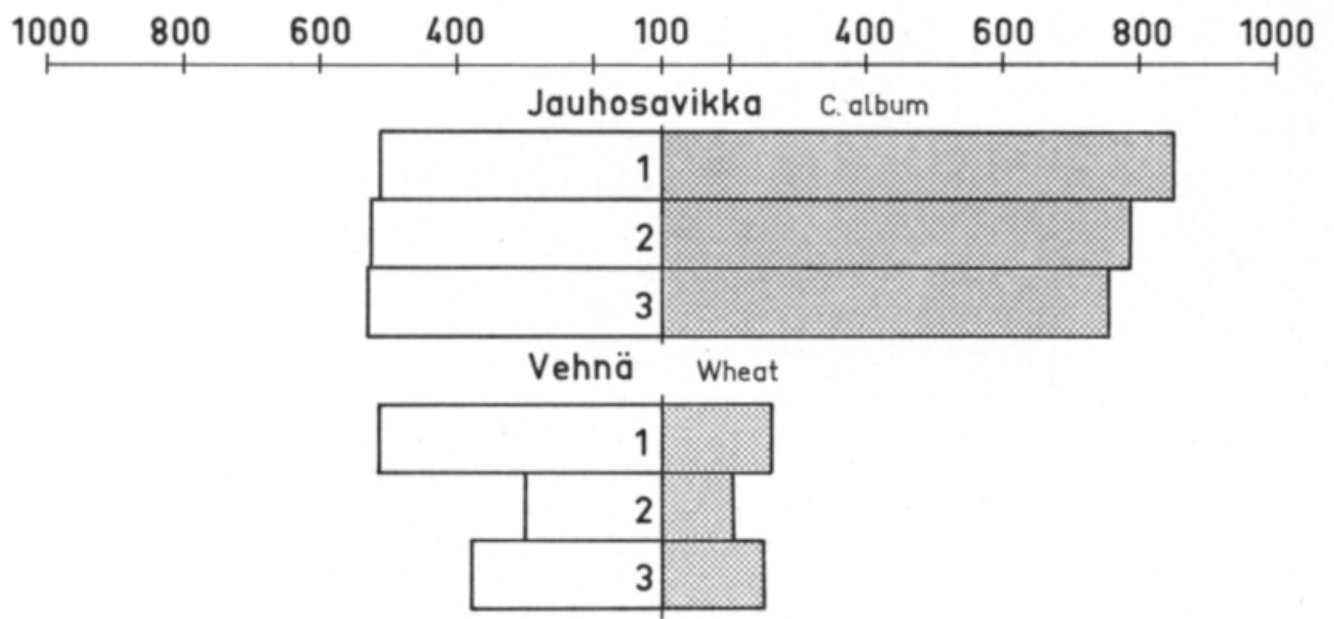

\section{Puhdas kasvusto Pure stand}

Sekakasvusto Mixed stand

Kuva 3. Poutajakson vaikutus jauhosavikan ja vehnän kuivapainon suhteelliseen lisäykseen yksilöä kohti istutuksesta lähtien. Poutajaksot: $1=$ ei poutaa, $2=$ jauhosavikan kukinnan alkaessa (vehnä orasasteella), $3=$ jauhosavikan täyden kukinnan aikana (vehnän tähkät tupessa).

Fig. 3. Effect of a dry-weather period on the relative increase in individual dry weights of $C$. a $l$ b $u$ m and wheat from the time of planting. $1=$ no dry-weather period, $2=d r y$ weather during early flowering of $C$. a $l$ bu $m$ (wheat at seedling stage), $3=d r y$ weather during full flowering of $C$. a l bu $\mathrm{m}$ (wheat ears enclosed in sheaths).

tuksesta vehnän sato aleni sekä puhtaassa että sekakasvustossa siinä määrin, että erilaisten kasvustojen väliset satoerot tasoittuivat. Kun pouta sattui vehnän tähkien ollessa tupessa, pysyi puhtaan vehnäkasvuston sato muiden kasvustojen satoa suurempana. Sekakasvustossa oli jauhosavikan sato pinta-alayksikköä kohti merkitsevästi suurempi kuin vehnän käsittäen keskimäärin $65.3 \%$ sadosta, vehnän osuuden jäädessä 34.7 prosentiksi.

Kasvien kilpailukykyä voidaan LAMPETERin (1959/60) mukaan kuvata valtauskertoimella, jonka laskemiseksi hän on kehittänyt kaavan $\mathrm{V}=\frac{\mathrm{a}}{\mathrm{b}}$. Siinä

$$
\begin{aligned}
& a=\text { lajin osuus seoksen sadosta ja } \\
& b=\text { lajin osuus puhtaitten kasvustojen satojen summasta. }
\end{aligned}
$$

Tätä kaavaa käyttäen laskettiin jauhosavikan ja vehnän valtauskertoimet kokeessa II, jossa yksilöitten kokonaislukumäärä astioissa oli yhtä suuri. Veden säännöstely aiheutti jauhosavikan ja vehnän valtauskertoimissa vähäistä vaihtelua, joka kuitenkin osoittautui satunnaiseksi. Jauhosavikan aggressiivisuutta kilpailijana vehnään nähden kuvastaa sen keskimääräinen valtauskertoimen arvo 1.5, joka oli 2.5-kertainen vehnän valtauskertoimeen 0.6 verrattuna. 


\section{Tulosten tarkastelu}

K o e I. Koelämpötilojen vaikutus jauhosavikkaan ja kauraan ilmeni lähinnä siten, että $24^{\circ} \mathrm{C}: n$ lämpötila joudutti molempien lajien kehitystä. Sen vuoksi myös kasvien sadot poikkesivat toisistaan huomattavasti kummassakin lämpötilassa. Päinvastoin kuin aikaisemmissa tutkimuksissa (ERvı̈ 1972) jauhosavikan sato oli suurempi $24^{\circ}$ kuin $12^{\circ}$ C:ssa (kuva 1). Syynä siihen oli ilmeisesti lyhyt koejakso, jonka aikana jauhosavikan voimakkain vegetatiivinen kasvu ei $12^{\circ} \mathrm{C}$ :ssa lainkaan ehtinyt alkaa. Edellä mainitut aikaisemmat tutkimukset nimittäin osoittivat, että jauhosavikan sato nousi $12^{\circ} \mathrm{C}$ :ssa jyrkästi vasta haarojen kehittyessä. Vaikka jauhosavikka yleensä tunnetaan vaatimattomana kasvina, näyttää siltä, ettei se pystynyt käyttämään alhaista lämpötilaa hyväkseen niin tehokkaasti kuin kaura, koska $12^{\circ} \mathrm{C}$ :n lämpötila hidasti enemmän jauhosavikan (asetelma s. 141) kuin kauran kasvua.

Näennäisestä suuruudestaan huolimatta ero jauhosavikan yksilönpainoissa seka- (sl. 65) ja puhtaan kasvuston (sl. 100) välillä ei ollut tilastollisesti merkitsevä. Syynä lienee se, että aineistossa hajontaa lisäsivät erityisesti lämpötilojen yksilönpainoissa aiheuttamat huomattavat erot. Sitäpaitsi yksilönpainoissa esiintyi myös kerranteiden välillä tavallista suurempaa vaihtelua. Jauhosavikan ja kauran kilpailu sekakasvustossa aiheutti kauran yksilönpainoon keskimäärin $20 \%: n$ alennuksen puhtaaseen kasvustoon verrattuna. Painon alenemiseen vaikutti osaltaan sekakasvuston yksilömäärän lisääntyminen kaksinkertaiseksi puhtaaseen kaurakasvustoon verrattuna.

Huolimatta vähäisemmästä yksilömäärästä nousi puhtaan kaurakasvuston kuivaainesato lähes yhtä suureksi kuin sekakasvuston (kuva 1). Luontaisen versomiskykynsä ansiosta kaura rehevöityi sekakasvustossakin niin, että sen osuus sadosta oli huomattavasti suurempi $(77.4 \%$ ) kuin jauhosavikan (22.6\%). Myös Staniforth ja Weber (1956) ovat todenneet rikkaruohottoman viljelykasvikasvuston tuottaneen lähes yhtä suuren sadon kuin rikkakasvien ja viljelykasvin sekakasvuston.

K o e I I. Jauhosavikan on todettu sietävän hyvin kuivuutta (WrLlıams 1964). Tämä ilmeni myös kokeessa II, jossa veden säännöstely ei vaikuttanut jauhosavikkaan siitä huolimatta, että kasvit joutuivat kestämään poutaa keskimäärin 20 vuorokautta. Sen sijaan vehnän sato aleni voimakkaasti poutajakson vaikutuksesta (taulukko 3).

FABriciuksen ja NAlewajan (1968) tutkimuksissa vehnä osoittautui kiertotatarta paremmaksi kuiva-aineentuottajaksi puhtaassa kasvustossa, mutta sekakasvustossa aiheutti kilpaileva laji vähennyksen kuiva-aineen kasvussa. Samassa tutkimuksessa maan kosteuden lisääntyessä kasvoi vehnän kuiva-ainesato puhtaassa kasvustossa enemmän kuin kiertotattaren. Jauhosavikan ja vehnän kasvaessa astiakoehallissa kummankin kuiva-ainesato yksilöä kohti lisääntyi puhtaissa kasvustoissa suhteellisesti yhtä paljon, kun vettä oli riittävästi saatavissa (kuva 3). Poutajakso samoin kuin kilpaileva laji sekakasvustossa pienensivät vehnän, mutta eivät haitanneet jauhosavikan kuiva-ainesadon lisääntymistä yksilöä kohti.

Tutkiessaan usean kasvilajin kilpailua Bornkamm (1961) totesi, että yksilöitten paino aleni sitä enemmän, mitä voimakkaamman kilpailijan kanssa ne kasvoivat. Tämän mukaan jauhosavikan lajinsisäinen kilpailu astiakoehallissa näytti olleen ankarampaa kuin kilpailu vehnän kanssa, koska jauhosavikan yksilönpaino kokeen päättyessä oli 
n. $50 \%$ suurempi seka- kuin puhtaassa kasvustossa. Vehnän yksilönpainoa puhtaaseen vehnäkasvustoon verrattuna pienensi kilpailu jauhosavikan kanssa keskimäärin $39 \%$.

Jauhosavikan osuus sekakasvuston sadosta oli huomattavasti suurempi $(65.3 \%)$ kuin vehnän $(34.7 \%$ ). Kun istutusvaiheessa määritettyjen yksilönpainojen perusteella lasketaan silloinen kuiva-ainesadon jakautuminen jauhosavikan ja vehnän osalle, osoittautuu se päinvastaiseksi kuin korjuuvaiheessa: jauhosavikan osuus oli $36.4 \%$ ja vehnän $63.3 \%$. Jauhosavikka on siis pystynyt tehokkaasti syrjäyttämään vehnän. Myös jauhosavikan korkea valtauskerroin vehnään nähden osoittaa vehnän olleen heikompi kilpailija. RoвBINs ym. (1952) sekä Shadbold ja Holm (1956) ovat todenneet kasvun alussa nopeasti kehittyvän lajin yleensä hyötyvän kilpailusta. Tämä lienee osaltaan syynä jauhosavikan menestymiseen astiakoehallissa vehnän kanssa kilpaillessaan. Istutusvaiheessa jauhosavikka mahdollisesti oli jonkin verran edellä vehnän vastaavasta kehitysasteesta (n. 4lehtiaste) ja kehittyi edelleen tätä nopeammin (asetelma s. 143). Toisaalta myös veden säännöstely, joka häiritsi vehnän kasvua haittaamatta jauhosavikkaa (taulukko 3), lienee suonut jauhosavikalle-paremmat kilpailuedellytykset.

\section{Tiivistelmä}

K o e I. Tutkimukset, jotka koskivat keskenään kilpailevaa jauhosavikkaa ja kauraa osoittivat seuraavaa:

1. Jauhosavikka ja kaura kehittyivät huomattavasti nopeammin $24^{\circ}$ kuin $12^{\circ} \mathrm{C}$ :ssa. Kumpikin laji tarvitsi $24^{\circ} \mathrm{C}$ :ssa alkukehitykseensä samat lämpötilasummat 2-lehtiasteelle saakka. Siitä eteenpäin kehittyäkseen jauhosavikka tarvitsi pienemmät lämpötilasummat kuin kaura. Lämpötilan ollessa $12^{\circ} \mathrm{C}$ kauran alkukehitykseen 2-lehtiasteelle saakka riitti pienempi lämpötilasumma kuin jauhosavikalle. Alhainen lämpötila hidasti enemmän jauhosavikan kuin kauran painon nousua.

2. Lajinsisäisen ja kauran kanssa tapahtuneen kilpailun vaikutuksessa jauhosavikan yksilönpainoon ei ilmennyt eroja. Kilpailu jauhosavikan kanssa pienensi kauran yksilönpainoa ja kokonaissatoa.

3. Jauhosavikan ja kauran puhtaat kasvustot tuottivat pinta-alayksiköltä lähes yhtäsuuret kuiva-ainesadot kuin näiden sekakasvusto. Jauhosavikan sato sekakasvustossa jäi pienemmäksi kuin kauran käsittäen keskimäärin $22.6 \%$ kokonaissadosta.

K o e I I. Poutajakson vaikutusta keskenään kilpailevaan jauhosavikkaan ja vehnään selvittäneet tutkimukset osoittivat seuraavaa:

4. Poutajakso ei vaikuttanut jauhosavikkaan, mutta alensi vehnän yksilönpainoa ja kokonaissatoa sekä jauhosavikan ja vehnän sekakasvuston satoa. Vehnäsato pieneni voimakkaimmin, kun poutakausi sattui vehnän ollessa orasasteella.

5. Kilpailu jauhosavikan kanssa alensi vehnän yksilönpainoa ja kokonaissatoa. Jauhosavikan yksilönpainoa pienensi lajinsisäinen kilpailu enemmän kuin kilpailu vehnän kanssa. Jauhosavikan yksilönpaino lisääntyi kasvuaikana suhteellisesti enemmän kuin vehnän. Sen painonlisäys yksilöä kohti oli suurempi, vehnän taas pienempi seka- kuin puhtaassa kasvustossa.

6. Puhdas jauhosavikkakasvusto tuotti pienimmän ja vehnäkasvusto suurimman sadon pinta-alayksiköltä. Sekakasvuston sadosta jauhosavikan osuus oli keskimäärin $65.3 \%$ ja vehnän $34.7 \%$. Vehnään nähden korkeampi valtauskerroin osoitti jauhosavikan tätä voimakkaammaksi kilpailijaksi. 


\section{KIRJALLISUUTTA}

Baker, C., Holmes, H. \& Pfeiffer, R. 1963. Selective control of Chenopodium album in kale with methylmercapto triazines. Weed Res. 3:109-127.

Bornкaмm, R. 1961. Zur Lichtkonkurrenz von Ackerunkräutern. Flora 151:126-143.

Dawson, J. H. 1964. Competition between irrigated beans and annual weeds. Weeds 12:206-208.

ERviö, L.-R. 1971. The effect of intra-specific competition on the development of Chenopodium album L. Weed Res. 11:124-134.

ERvıö, L.-R. 1972. Kasvuston tiheyden ja lämpötilan vaikutus jauhosavikan (Chenopodium album L.) ja sen sadon kehittymiseen. Maatal.tiet. Aikak. 44:29-40.

Fabricius, L. \& Nalewaja, J. D. 1968. Competition between wheat and wild buckwheat. Weed Sci. $16: 204-208$.

Granströм, B. 1962. Studies över ogräs i vårsådda grödor. Stat. Jorbr.förs. Medd. 130:1-188.

HoFer, H. 1970. Ưber die Zusammenhänge zwischen der Düngung und der Konkurrenzfähigkeit ausgewählter Naturwiesenpflanzen. Diss. 4500:1-70. Zürich.

Idris, H. \& MrLthorpe, F. L. 1966. Light and nutrient supplies in the competition between barley and charlock. Oecologia Pl. 1:143-164.

Jưsel.A, T. 1962. Ein zur unmittelbaren Messung der Verdunstung der Bodenoberfläche benutztes Verfahren. Z. Kulturtechnik 3:137-142.

KосH, W. 1967. Untersuchungen zur Konkurrenzwirkung von Kulturpflanzen und Unkräutern aufeinander. Weed Res. 7:22-28.

LAmpeter, W. 1959/60. Gegenseitige Beeinflussung höherer Pflanzen in bezug auf Spross- und Wurzelwachstum, Mineralstoffgehalt und Wasserverbrauch - untersucht an einigen wirtschaftlich wichtigen Futterpflanzen. Wiss. Z. Univ. Leipzig 9:611-722. (Ref. Hofer, H. 1970).

Martin, P. \& Rademacher, B. 1960. Studies on the mutual influences of weeds and crops. The biology of weeds. p. 143-152. Oxford.

Rademacher, B. 1964. Beginn der Konkurrenz zwischen Getreide und Unkraut. Z. Pfl.krankh. Pfl.path. Pfl.schutz 1:88-93.

Rademacher, B., Kolb, F. \& Börner, H. 1961. Untersuchungen über die gegenseitige Beeinflussung von Kulturpflanzen und Unkräutern in Wasserkultur. Weed Res. 1:44 - 58.

Robbins, W. W., Grafts, A. S. \& Raynor, R. N. 1952. Weed control. 503 p. New York.

Sнарвоцт, C. A. \& Holм, L. G. 1956. Some quantitative aspects of weed competition in vegetable crops. Weeds $4: 111-123$.

Wrlliams, J. T. 1964. A study of the competitive ability of Chenopodium album. Interference between kale and C. album in pure stands and in mixtures. Weed Res. 4:283-295. 